\title{
Carbon and oxygen isotope geochemistry of Ediacaran outer platform carbonates, Paraguay Belt, central Brazil
}

\author{
CLAUDIO RICCOMINI ${ }^{1}$, AFONSO C.R. NOGUEIRA ${ }^{2}$ and ALCIDES N. SIAL ${ }^{3}$ \\ ${ }^{1}$ Departamento de Geologia Sedimentar e Ambiental, Instituto de Geociências, Universidade de São Paulo \\ Rua do Lago, 562, 05508-080 São Paulo, SP, Brasil \\ ${ }^{2}$ Departamento de Geologia, Centro de Geociências, Universidade Federal do Pará, \\ Caixa Postal 1611, 66075-900 Belém, PA, Brasil \\ ${ }^{3}$ NEG-LABISE, Departamento de Geologia, Universidade Federal de Pernambuco, \\ Caixa Postal 7852, 50670-000 Recife, PE, Brasil \\ Manuscript received on August 8, 2006; accepted for publication on February 7, 2007; \\ contributed by ALCIDES N. SIAL*
}

\begin{abstract}
After the late Cryogenian glaciation the central region of Brazil was the site of extensive deposition of platformal carbonates of the Araras Group. This group includes a basal cap carbonate sequence succeeded by transgressive, deep platform deposits of bituminous lime mudstone and shale. Facies and stratigraphic data combined with carbon and oxygen isotopic analyses of the most complete section of the transgressive deposits, exposed in the Guia syncline, were used to evaluate the depositional paleoenvironment and to test the correlation of these deposits along the belt and with other units worldwide. The studied succession consists of $150 \mathrm{~m}$ thick tabular beds of black to grey lime mudstone and shale with predominantly negative $\delta^{13} \mathrm{C}_{\mathrm{PDB}}$ values around -2.5 to $-1 \%$. The $\delta^{13} \mathrm{C}_{\mathrm{PDB}}$ profile of Guia syncline shows a clear correlation with the upper portion of Guia Formation in the Cáceres region, about $200 \mathrm{~km}$ to the southwest. The $\delta^{13} \mathrm{C}_{\mathrm{PDB}}$ profile of the Araras Group is comparable with $\delta^{13} \mathrm{C}_{\mathrm{PDB}}$ profiles of Ediacaran units of the southern Paraguay Belt, western Canada, and the Congo and Kalahari cratons. Moreover, facies distribution, stratigraphy and the carbon isotopic profile of the Araras Group match the middle Tsumeb Subgroup in Namibia, which reinforces the Ediacaran age assigned to the Araras Group.
\end{abstract}

Key words: carbon and oxygen isotopes, Ediacaran, Araras Group, Guia Formation, Amazon Craton, glaciation.

\section{INTRODUCTION}

The transition zone between the southern margin of the Amazon Craton and the northern portion of the Paraguay Belt is an extensive thrust-and-fold belt formed during the final stages of Brasiliano-Pan-African orogenesis (ca. 540-500 Ma, Almeida 1984, Trompette 2000, Alvarenga et al. 2000), as a result of the convergence and collision of the Amazônia (West), São Francisco-Congo (East) and Paraná (South) blocks (Almeida 1984, Basei and Brito Neves 1992, Alkmim et al. 2001). It is inter-

\footnotetext{
*Member Academia Brasileira de Ciências

Correspondence to: Claudio Riccomini

E-mail: riccomin@usp.br
}

preted as a foreland basin (cf. Trompette 1994) whose sedimentary deposits record a late Neoproterozoic depositional history including extensive glaciation, anomalous carbonate deposition, syn-sedimentary seismicity and isotopic excursions (Nogueira et al. 2003). The final extensional events allowed granite emplacement at about $500 \mathrm{Ma}$ (Almeida and Mantovani 1975).

After a severe glaciation that finished at ca. $630 \mathrm{Ma}$ this region was the site of extensive deposition of platformal carbonates of the Araras Group, now exposed along the southern border of the Amazon Craton and at the northern Paraguay Belt (Fig. 1). A carbonate succession over $600 \mathrm{~m}$ thick overlies late Cryogenian glacio- 


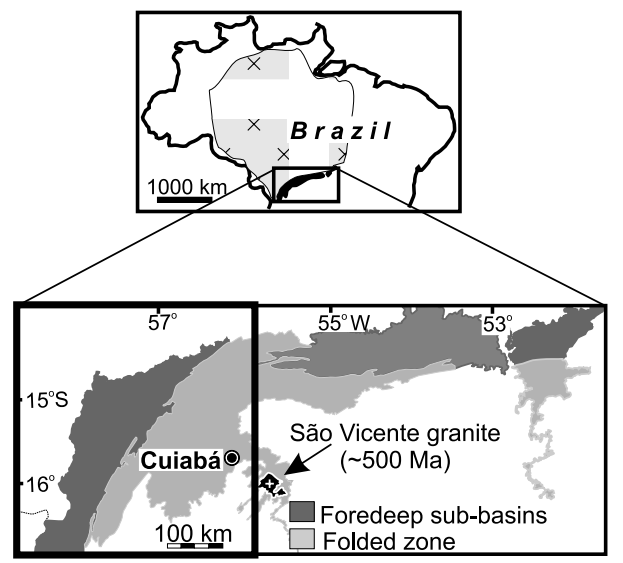

$\therefore$ Alto Paraguai Group and Diamantino Fm.

$\square$ Araras Group

$\triangle_{\triangle}$ Late Cryogenian diamictites

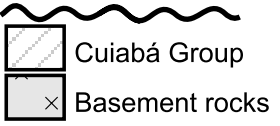

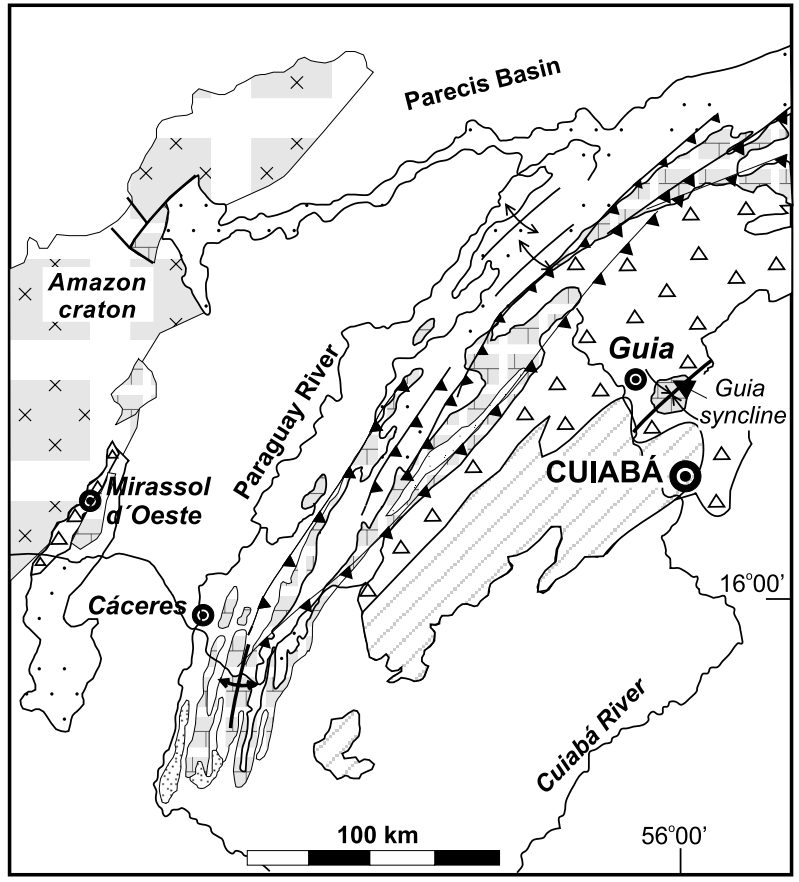

SE

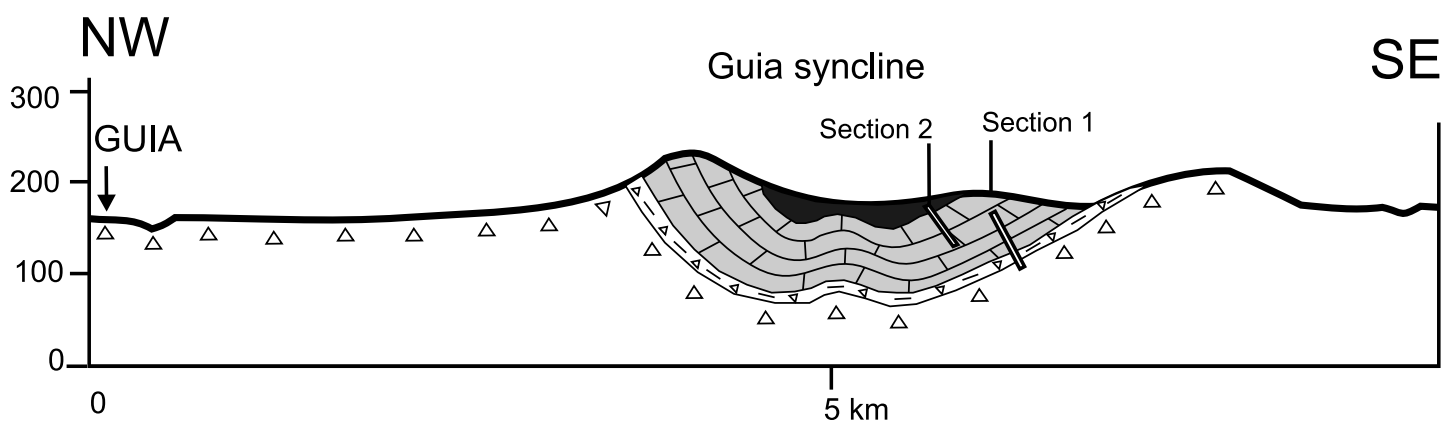

Fig. 1 - Geologic map of Paraguay Belt with location of the Guia region and detailed geologic section of Guia syncline (after Almeida 1964) with location of studied profiles.

genic diamictites and includes the first well-documented cap carbonate sequence in South America (Nogueira et al. 2003). Paleomagnetic data indicate a low paleolatitude $\left(22+6 /-5^{\circ}\right)$ for the Amazon block, right after deposition of the diamictite (Trindade et al. 2003). The post-glacial cap carbonate was succeeded by an impressive transgression recorded by a thick accumulation of bituminous lime mudstone and shale, discontinuously distributed for more than $400 \mathrm{~km}$ in the region, and considered as deep platform deposits (Nogueira et al. 2003). The most complete section of these deposits occurs in the Nossa Senhora da Guia mine, preserved in an asymmetric syncline with NE-SW-oriented axis, located $30 \mathrm{~km}$ northwest of Cuiabá (Fig. 1). Facies and stratigraphic data combined with carbon and oxygen analysis were used to evaluate the depositional paleoenvironment and to test the correlation of these deposits along the belt and with other units worldwide.

\section{STRATIGRAPHY AND AGE}

Three major lithostratigraphic units may be distinguished in the region (Fig. 2), from base to top: the Puga Formation (diamictite, siltstone with dropstones); the Araras Group (dolostone, limestone, sandstone); and Alto Paraguay Group (sandstone, mudstone and calca- 


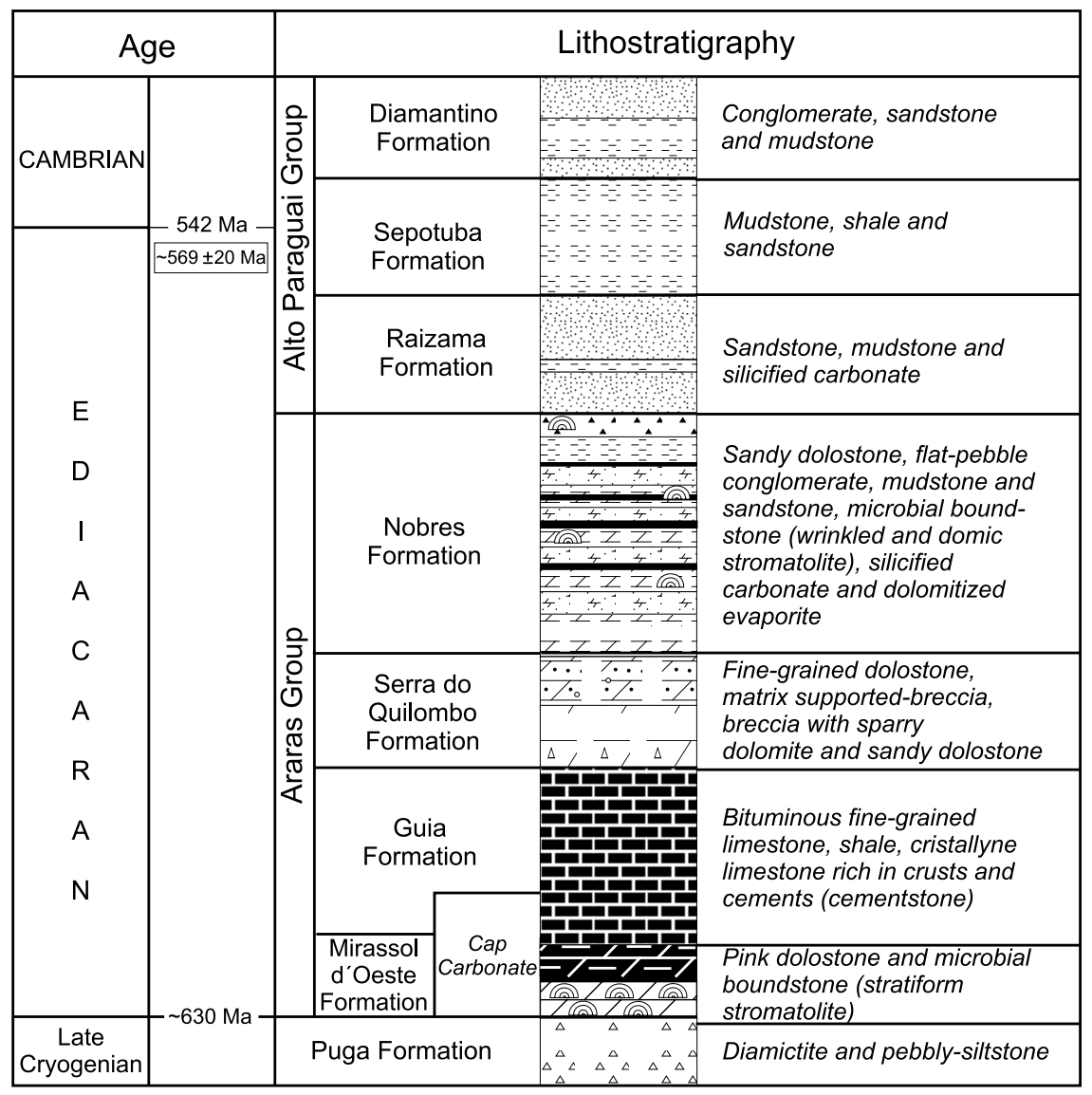

\begin{tabular}{|c|c|c|}
\hline $\begin{array}{l}\text { bituminous } \\
\text { limestone/shale }\end{array}$ & $\therefore$ silicified-dolostone & mudstone \\
\hline $\begin{array}{l}\text { 定园 bituminous } \\
\text { dolostone }\end{array}$ & $\div$ dolostone/sandstone & sandstone \\
\hline$\angle$ dolostone & $\because \quad \begin{array}{l}\text { sandy dolostone and } \\
\text { matrix-supported breccia }\end{array}$ & ( stromatolite \\
\hline$\left[\Delta_{\Delta}^{\Delta}{ }_{\Delta}\right.$ diamictite & $\begin{array}{l}\text { breccia with sparry } \\
\text { dolomite cement }\end{array}$ & secondary chert \\
\hline
\end{tabular}

Fig. 2 - Stratigraphic units of northern Paraguay Belt (after Nogueira et al. 2007, modified). The inferred ages based in correlation with Marinoan glaciation and $\mathrm{Rb} / \mathrm{Sr}$ age for Sepotuba Formation are debatable.

renite). The laterally extensive Araras Group is interpreted as platform carbonate deposits, as suggested by its homogeneous, predominantly deep-water lithofacies exposed on the craton and in the Paraguay Belt. The stratigraphic succession of the Araras Group includes megacycles, cycles and event beds distributed in most of $600 \mathrm{~m}$ (composite section) with distinct isotopic signatures (Nogueira et al. 2007). In particular, the cap carbonate sequence (Hoffman and Schrag 2002) is characterized by the presence of the Puga cap carbonate, predominance of deep-water deposits, $\mathrm{CaCO}_{3}$-oversaturation events, and $\delta^{13} \mathrm{C}$ with predominantly negative values (Nogueira et al. 2003).

The carbonate rocks of the Araras Group have not yet been dated radiometrically, nor have tuffs or volcanic rocks been identified. Reported $\mathrm{Rb}-\mathrm{Sr}$ ages for mudrocks of the overlying Alto Paraguay Group (569 \pm $20 \mathrm{Ma}$, Cordani et al. 1978, Bonhomme et al. 1982; and $660 \pm 60 \mathrm{Ma}$, Cordani et al. 1985) are open to debate. The Rb-Sr age of the São Vicente Granite (483 \pm 8 Ma, 
Almeida and Mantovani 1975), an anorogenic granite intruding the Cuiabá Group (a lateral equivalent of the studied units of the Araras Group), provides a minimum age for the sedimentary succession of the Paraguay Belt. The age of the Araras Group has been inferred in part on the basis of lithostratigraphic correlation with carbonate rocks of the Corumbá Group, which crop out about $500 \mathrm{~km}$ south of the study area. Nevertheless, this correlation is speculative because facies, sedimentary environments, chemostratigraphy of carbonates and fossils are different (P.C. Boggiani, unpublished data, Gaucher et al. 2003, Alvarenga et al. 2004, Figueiredo et al. 2006). Although lithologically similar, diamictites assigned to the Puga Formation in its type area (southern Paraguay Belt) and in the northern part of the belt may be different stratigraphic units with different ages. Recent descriptions of more than one glacial horizon both in the Corumbá Group (Boggiani et al. 2004) and in the northern Paraguay Belt (Serra Azul Formation, Figueiredo et al. 2004, 2006, Alvarenga et al. 2007) make lithostratigraphic correlations more complex. The Corumbá Group is notable for the occurrence of Cloudina, an index fossil of the latest Neoproterozoic, and considered contemporaneous with the Ediacara biota (Germs 1972, Grant 1990, M.F. Zaine, unpublished thesis, Zaine and Fairchild 1985, 1992, Gaucher et al. 2003). The Araras and Corumbá groups overlain glacial deposits.

Reported $\delta^{13} \mathrm{C}_{\mathrm{PDB}}$ values for the Araras Group (Nogueira et al. 2007) from Cáceres and Mirassol d'Oeste regions (Fig. 1), interpreted as representative of the original seawater $\left(\delta^{18} \mathrm{O}_{\mathrm{PDB}}>-10 \%\right.$, Jacobsen and Kaufman 1999), exhibit a trend from strongly negative values around $-9 \%$ at the base to positive values at the top of the succession (Fig. 3). The cap dolostone succession is composed of moderately deep platform deposits (Mirassol d'Oeste Formation) overlain by limestone rich in crusts and cements with $\delta^{13} \mathrm{C}_{\mathrm{PDB}}$ values around -5 to $-4 \%$ (lower Guia Formation). The anoxic, deep-platform limestone succession (upper Guia Formation) overlying the cap carbonate succession shows almost constant $\delta^{13} \mathrm{C}_{\mathrm{PDB}}$ values around -2.5 to $-1 \%$ (Fig. 3). Up section, a switch to positive values $(+0.1$ to $+0.3 \%$ ) occurs in dolomites deposited in shallow-platform and peritidal environments (Serra do Quilombo and Nobres formations).

\section{SAMPLING AND ANALYTICAL METHODS}

Sampling for C- and O-isotope analyses were performed on 38 fine-grained limestone samples, collected along $150 \mathrm{~m}$ of two stratigraphic sections of the Guia Formation, organized in a composite stratigraphic profile representative of the proposed stacking for the Araras Group (Fig. 3). As the carbonate succession of this area was affected by low-grade metamorphism, homogeneous samples with little diagenetic or metamorphic alteration were selected, although some dolomitized samples were also analyzed. Fractured, mineral-filled and weathered zones were avoided. Samples were micro-drilled with a $1 \mathrm{~mm}$ drill.

Carbon isotope analyses were performed at the Stable Isotope Laboratory (LABISE) of the Department of Geology, Federal University of Pernambuco, Brazil. $\mathrm{CO}_{2}$ gas was extracted from powdered carbonate in a high vacuum line after reaction with $100 \%$ phosphoric acid at $25^{\circ} \mathrm{C}$ for one day (three days were allowed when dolomite was present). The $\mathrm{CO}_{2}$ was analyzed in a double inlet triple collector SIRA II mass spectrometer following cryogenic cleaning. The results are reported in conventional notation in per mil (\%o) relative to the VPDB (Vienna - PDB or Pee Dee Belemnite) standard. VPDB is a scale recognized by the National Institute for Standards and Technology (NIST) of USA that is used for reporting relative abundances of ${ }^{13} \mathrm{C}$ or ${ }^{18} \mathrm{O}$ via the delta notation. The uncertainties of isotope measurements were $0.1 \%$ for carbon and $0.2 \%$ for oxygen, based on multiple analyses of an internal laboratory standard (BSC, Borborema skarn calcite).

\section{RESULTS}

The Outer Platform Deposits in the Guia Syncline

The sedimentary succession in the Guia syncline consists of tabular beds of black to grey lime mudstone and shale $150 \mathrm{~m}$ in thickness (Fig. 4). Silt and fine sand are disseminated in the limestones and pyrite crystals are found locally. These rocks are disposed in compositionally uniform and laterally extensive beds for dozens of meters in the Nossa Senhora da Guia mine, but certainly extends for more than $200 \mathrm{~km}$ to the southwest, reaching the region of Cáceres (Figs. 1, 2). The main sedimentary structure in these rocks is the even parallel lamination 


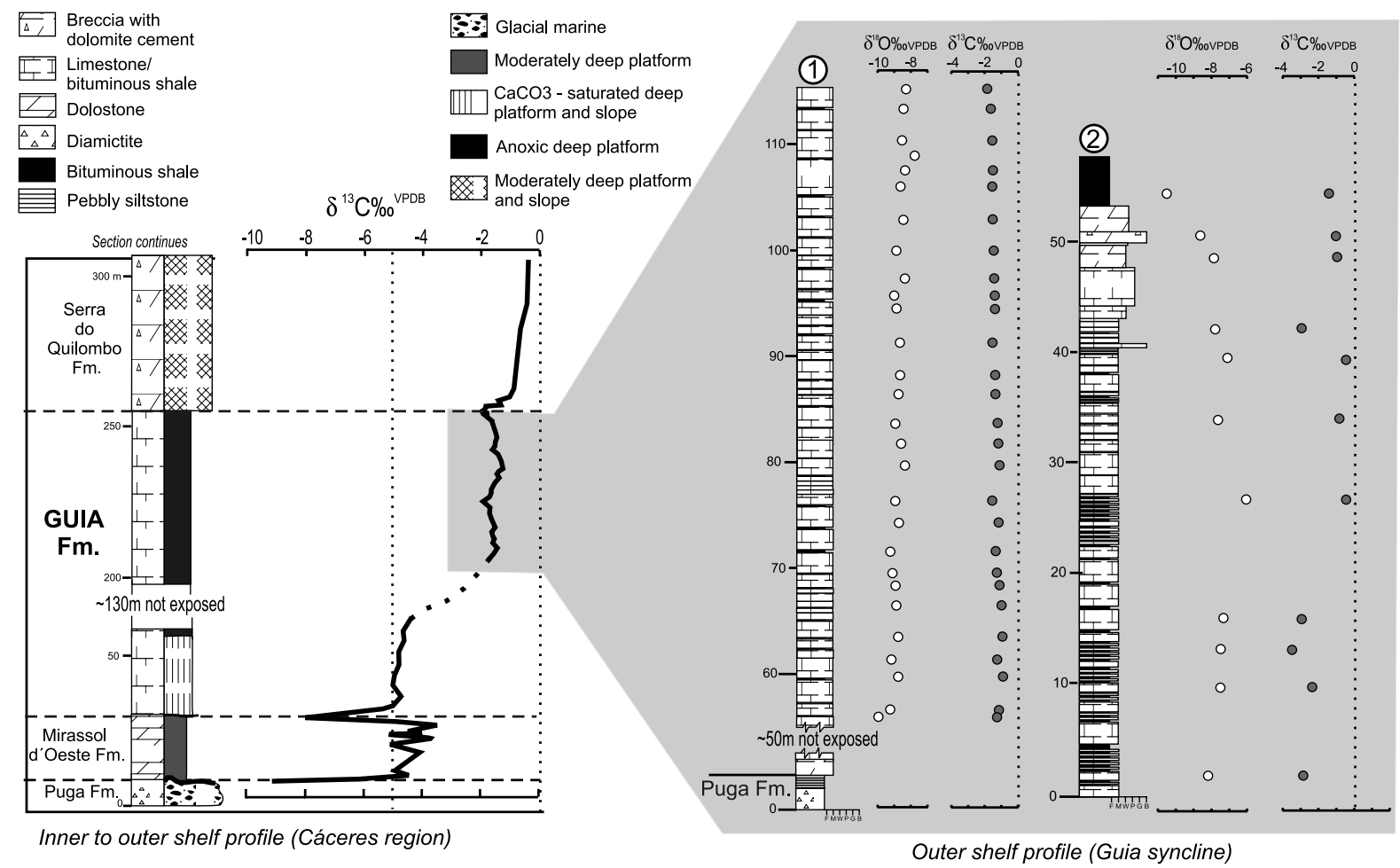

Fig. 3 - Isotopic correlation of outer shelf platform deposits of Cáceres and Guia regions. The $\delta^{13} \mathrm{C}_{\mathrm{PDB}}$ profiles are perfectly comparable and the measured sections in the Guia syncline can be correlated to the top of Guia Formation.

but cross-lamination occurs locally associated with thin beds of intraclastic packstone. This succession overlies a diamictite with abundant silty-matrix or gradedpebbly siltstone. The first meters of limestone above the diamictite are dolomitized and exhibit a pinkish color. A level of intensely dolomitized breccia with clasts of fine limestone occurs at the top of section 2 (Fig. 5).

The deep platform setting is indicated by the predominance of low energy carbonate facies (laminated lime mudstone) and suspension deposits (shale). Their distribution in monotonous, laterally extensive beds for more than $200 \mathrm{~km}$, suggest deposition into an ample deep platform (Pfeil and Read 1980, Coniglio and James 1990). The dark color of lime mudstone associated with bituminous and pyritous shale indicate anoxic conditions responsible for the accumulation and preservation of organic matter. Weak to moderate currents caused ripple migration. Locally brecciated limestone beds were accumulated within the slope setting (Coniglio and Dix 1992).

The position of the Guia syncline, more than
$200 \mathrm{~km}$ far from the craton, suggests that the studied succession represents the most distal part of Araras carbonate platform.

\section{AND O ISOTOPES}

The $\delta^{13} \mathrm{C}_{\mathrm{PDB}}$ values for the carbonate succession of the Guia syncline (Fig. 3) are interpreted as reflecting original seawater composition $\left(\delta^{18} \mathrm{O}_{\mathrm{PDB}}>-10 \%\right)$, which is corroborated by available $\mathrm{Mn} / \mathrm{Sr}<2$ values (Alvarenga et al. 2004). In section $1 \delta^{13} \mathrm{C}_{\mathrm{PDB}}$ values are uniform, ranging from -1 to $-2.5 \%$. These negative values indicate that the low metamorphic overprint did not affect the original $\delta^{13} \mathrm{C}_{\mathrm{PDB}}$ values (Fig. 3). Contrarily, in section 2 (Fig. 3) dolomitization may have modified slightly the $\delta^{13} \mathrm{C}_{\mathrm{PDB}}$ values that reach $-4 \%$, as indicated by $\delta^{18} \mathrm{O}_{\mathrm{PDB}}$ values lower than $-10 \%$. Strontium isotopic ratios up to 0.71151 in dolostones of the upper part of section 2 were related to low-grade metamorphism (Alvarenga et al. 2004). 


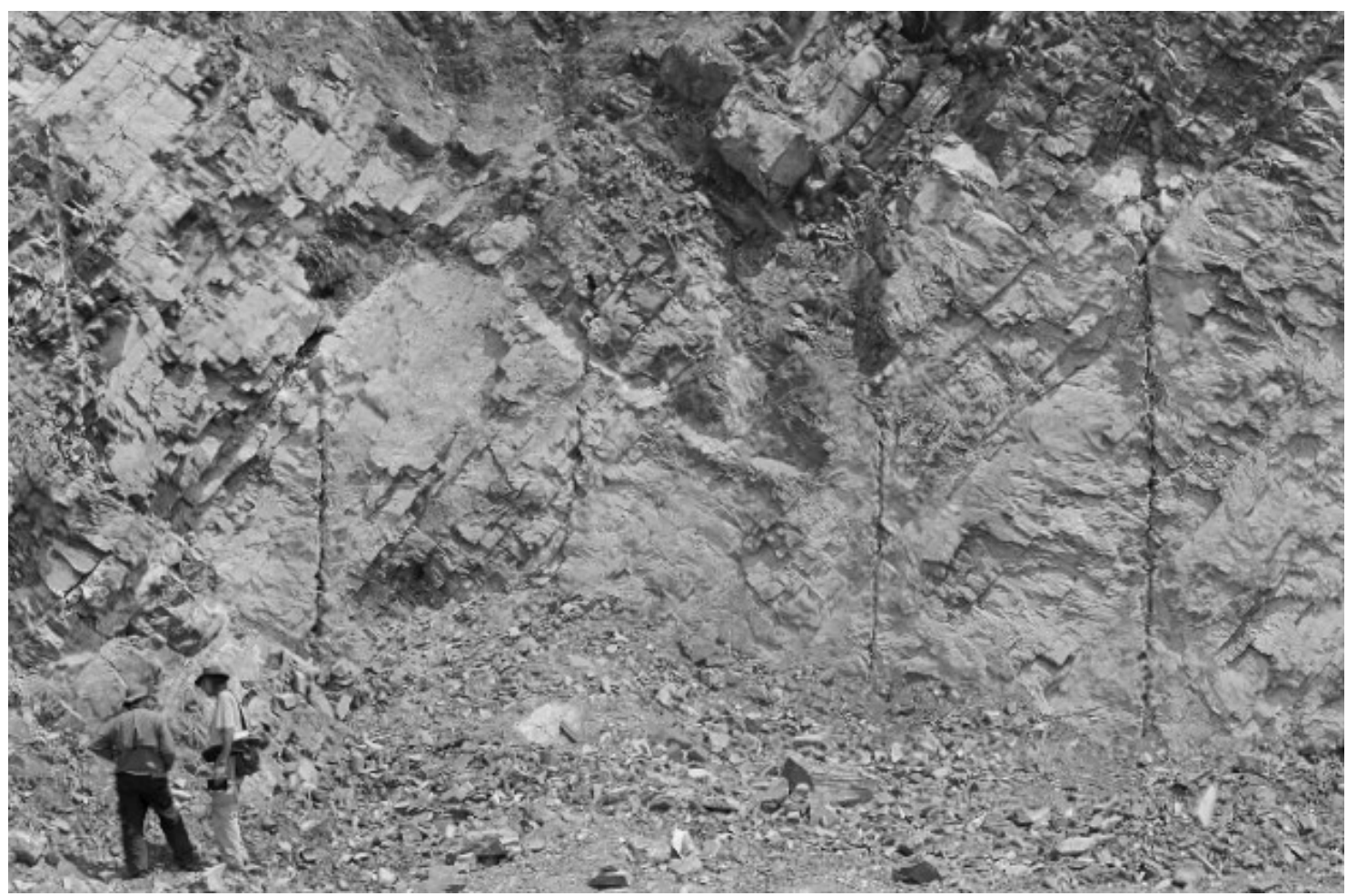

Fig. 4 - Tabular beds of black to grey lime mudstone and shale, Nossa Senhora da Guia Mine, Guia syncline.

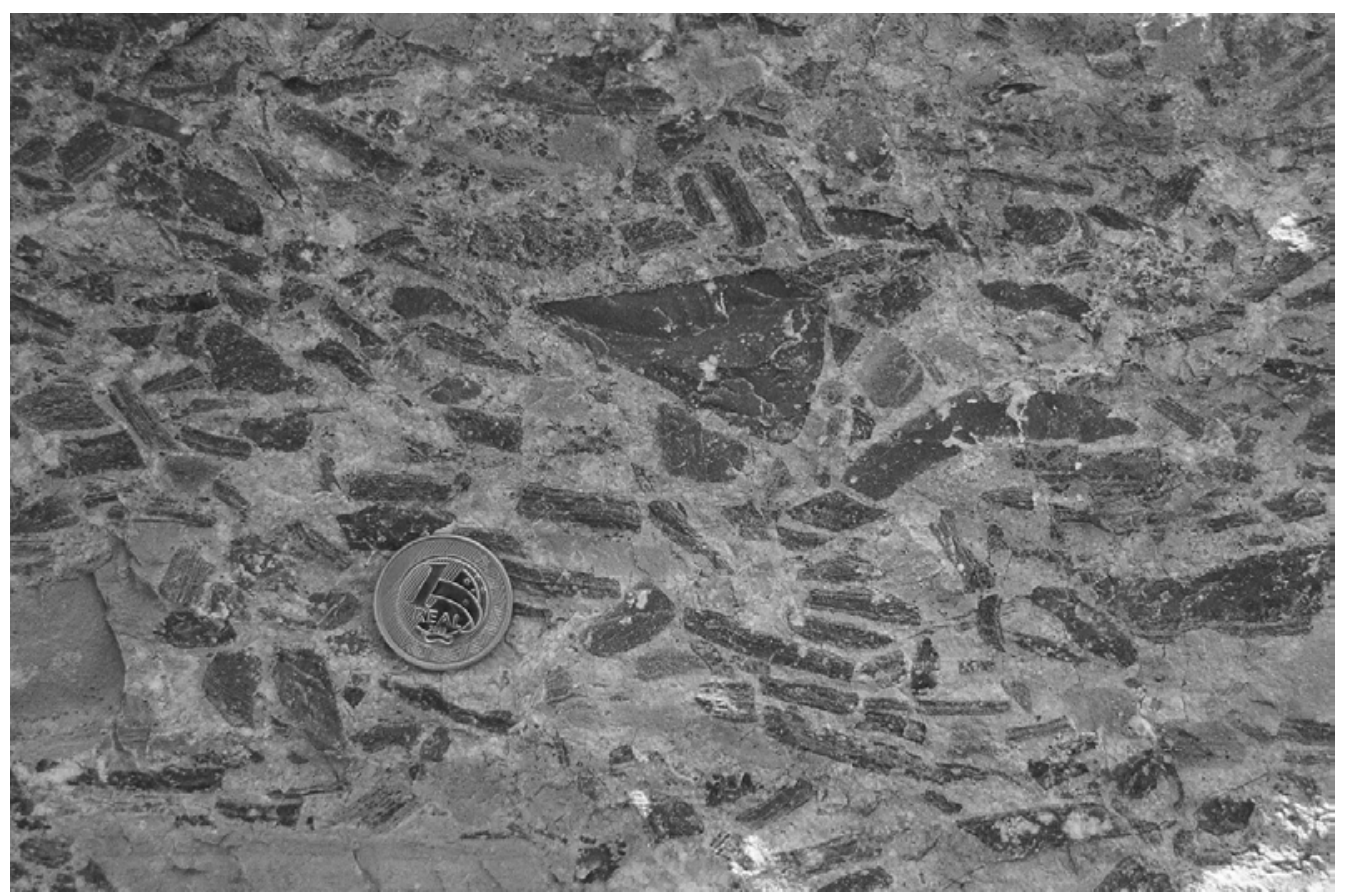

Fig. 5 - Dolomitized breccia with clasts of fine limestone at the top of the section, Nossa Senhora da Guia Mine, Guia syncline. 


\section{DISCUSSION}

\section{STRATIGRAPHIC IMPLICATIONS}

The isolated occurrence of bituminous limestone and shales in the Guia syncline has been previously positioned as a unit of the Cuiabá Group (Alvarenga et al. 2004), but our data points to a correlation of facies, paleoenvironmental significance and $\mathrm{C}$ and $\mathrm{O}$ isotopic values between the Cáceres and Guia regions (Fig. 3). The $\delta^{13} \mathrm{C}_{\mathrm{PDB}}$ profile at the Guia syncline shows a clear correlation with the upper portion of Guia Formation of Cáceres region, indicating that the succession in the Guia syncline belongs to the Araras Group (Figs. 2 and 3). The present-day distribution of this limestone within a syncline is related to relief evolution forming an isolated testimony.

Another observation concerns the relationship between pink dolostone and diamictite observed in the Guia syncline. This relationship is very similar to that observed in cap dolostones, but is still open to debate mainly because the dolomite is secondary (dolomitized limestone). Moreover, although no single cap carbonate develops the full set of anomalous sedimentary structures observed worldwide above glacial diamictites, this pink dolostone does not exhibit any of them. Thus, no evidence is available to support the interpretation that the lower part of the section of the Guia syncline is a cap carbonate.

It is difficult to estimate the elapsed time of erosion that represents the transgressive boundary between pebbly siltstone and the limestone, but it is possible to consider that the Guia Formation represents a long-term transgression deposit, not influenced by late Cryogenian glaciation.

\section{REGIONAL AND GLOBAL CORRELATIONS}

The $\delta^{13} \mathrm{C}_{\mathrm{PDB}}$ profile for more than $600 \mathrm{~m}$ of the Araras Group, with negative values around $0 \%$, is comparable with $\delta^{13} \mathrm{C}_{\mathrm{PDB}}$ profiles of post-late Cryogenian units of the Kalahari and Congo cratons, western Canada and southern Paraguay Belt (Nogueira et al. 2007). It is worth mentioning the similarities between the stratigraphy and the carbon isotopic profile of the Araras Group in Amazonia and the middle Tsumeb Subgroup in northern Namibia (Halverson et al. 2005). The similarity of facies associations with this Namibian succession is the base for tentatively correlate the Araras Group carbonate rocks to the post-Ghaub time-interval.

\section{CONCLUSIONS}

(1) The carbonate succession in the Guia syncline is represented by limestone and shale deposited in an outer platform setting;

(2) the clear comparison of facies, paleoenvironment and carbon isotopes with the Guia Formation of the Araras Group in Cáceres region indicate that the studied section in the Guia syncline belongs to the upper part of the Guia Formation;

(3) evidence that the pinkish dolostone beds overlying glaciogenic pebbly siltstone in the Guia syncline comprise a cap carbonate has yet to be found;

(4) the Guia Formation represents a first-order transgressive deposit postdating the late Cryogenian glaciation;

(5) the composite $\delta^{13} \mathrm{C}_{\mathrm{PDB}}$ profile of the Araras Group shows the same pattern of other post-Ghaub units worldwide; the similarity of facies associations with the Namibia succession lead us to assign the Araras Group carbonate rocks to the post-Ghaub (Ediacaran) time-interval.

\section{ACKNOWLEDGMENTS}

This research was developed with financial support of the Fundação de Amparo à Pesquisa do Estado de São Paulo (FAPESP grant \#00/02903-8) and Conselho Nacional de Desenvolvimento Científico e Tecnológico (CNPq grant \#304649/2005-8), to C. Riccomini. Thanks are due to P.F. Hoffman, T.R. Fairchild, R.I.F. Trindade and E. Font for discussions in the field, and to the anonymous referees for their helpful comments on the manuscript.

\section{RESUMO}

Após a glaciação do final do Criogeniano, a região central do Brasil foi palco de extensa deposição de carbonatos plataformais do Grupo Araras. Este grupo inclui na sua base uma seqüência de capa carbonática sucedida por depósitos transgressivos de calcilutitos betuminosos e folhelhos de plataforma 
profunda. Dados de fácies e estratigráficos combinados com análises isotópicas de carbono e oxigênio da seção mais completa desses depósitos transgressivos, expostos no sinclinal da Guia, foram empregados para avaliar o paleambiente deposicional e para testar a correlação desses depósitos ao longo da faixa e também com outras unidades de outros continentes. A sucessão estudada consiste de $150 \mathrm{~m}$ de espessura de camadas tabulares de calcilutitos e folhelhos cinza a pretos com valores de $\delta^{13} \mathrm{C}_{\mathrm{PDB}}$ negativos, entre $-2,5 \mathrm{e}-1 \%$. O perfil de $\delta^{13} \mathrm{C}_{\mathrm{PDB}}$ do sinclinal da Guia mostra clara correlação com a porção superior da Formação Guia da região de Cáceres, $200 \mathrm{~km}$ a sudoeste. O perfil de $\delta^{13} \mathrm{C}_{\mathrm{PDB}}$ do Grupo Araras é comparável aos perfis de $\delta^{13} \mathrm{C}_{\mathrm{PDB}}$ de outras unidades ediacaranas da parte sul da Faixa Paraguai, oeste do Canadá, e crátons do Congo e do Kalahari. Além disso, a distribuição de fácies, estratigrafia e o perfil isotópico do Grupo Araras são equiparáveis à porção média do Subgrupo Tsumeb na Namíbia, o que reforça a atribuição de idade Ediacarana para o Grupo Araras.

Palavras-chave: isótopos de carbono e oxigênio, Ediacarano, Grupo Araras, Formação Guia, Cráton Amazônico, glaciação.

\section{REFERENCES}

Alkmin FF, MarshaK S And Fonseca MA. 2001. Assembling West Gondwana in the Neoproterozoic: Clues from the São Francisco Craton region, Brazil. Geology 29: 319-322.

AlmeidA FFM. 1964. Geologia do centro-oeste matogrossense: Bol Div Geol Min DNPM, Rio de Janeiro, RJ, Brasil 219: 1-53.

Almeida FFM. 1984. Província Tocantins, setor sudoeste. In: Almeida FFM and Hasui Y (Eds), O Pré-Cambriano do Brasil, São Paulo, SP, Brasil, Blücher, p. 265281.

Almeida FFM and Mantovani MSM. 1975. Geologia e geocronologia do Granito de São Vicente, Mato Grosso. An Acad Bras Cienc 47: 451-458.

Alvarenga CJS, Moura CAV, Gorayeb PSS AND Abreu FAM. 2000. Paraguay and Araguaia Belt. In: Cordani ET AL. (Eds), Tectonic Evolution of South America, Rio de Janeiro, $31^{\text {st }}$ International Geological Congress, p. 183-193.

Alvarenga CJS, Santos RV and Dantas EL. 2004. C-O-Sr isotopic stratigraphy of cap carbonates overlying Marinoan-age glacial diamictites in the Paraguay Belt, Brazil. Precambrian Res 131: 1-21.
Alvarenga CJS, Figueiredo MF, Babinski M And PINHO FEC. 2007. Glacial diamictites of Serra Azul Formation (Ediacaran, Paraguay belt): Evidence of the Gaskiers glacial event in Brazil. J S Am Earth Sci, doi:10.1016/ j.jsames.2006.09.015.

Basei MAS ANd BRito Neves BB. 1992. Características geológicas da transição Proterozóico-Faneorozóico no Brasil. In: Gutierrez Marco JG et AL. (Eds), Paleozóico Inferior de Iberoamérica, Mérida, Universidad de Extremadura, p. 331-342.

Boggiani PC, FAIRCHILD TR AND RICCOMINI C. 2004. New level of diamictites in the Corumbá Group (Ediacaran), Paraguay belt, South America. In: SyMposium on NeOPRoterozoic-EARly PALEOZOIC Events in SW-GondWAnA, 1, Extended Abstracts, São Paulo, IGCP Project 478, p. 10-12.

Bonhomme MG, CoRdani UG, Kawashita K, Macedo MHF AND ThOMAs FILHo A. 1982. Radiochronological age and correlation of Proterozoic sediments in Brazil. Precambrian Res 18: 103-118.

Coniglio M AND Dix GR. 1992. Carbonate slopes. In: WALKeR RG AND JAMES N (Eds), Facies Models - Response to Sea Level Change, Ontario, Geological Association of Canada, p. 349-373.

CONIGLio M AND JAMES NP. 1990. Origin of fine-grained carbonate and siliciclastic sediments in an early Palaeozoic slope sequence, Cow Head Group, western Newfoundland. Sedimentology 37: 215-230.

Cordani UG, Kawashita K and Thomaz Filho A. 1978. Applicability of the rubidium-strontium methods to shales and related rocks. In: COHEE BV ET AL. (Eds), Contributions to the geologic time scale, Tulsa, Am Assoc Petrol Geol, p. 93-117.

Cordani UG, Thomaz Filho A, Brito Neves BB and KAWASHITA K. 1985. On the applicability of the Rb-Sr method to argillaceous sedimentary rocks: some examples from Precambrian sequences of Brazil. Giornale Geol 471: 253-280.

Figueiredo MF, Babinski M, Alvarenga CJS AND PINHO FEC. 2004. Diamictites overlying Marinoan-age carbonates of Araras Formation, Paraguay belt, Brazil: evidence of a new glaciation? In: SYMPOSIUM ON NEOPROTEROZOIC - EARLY PALEOZOIC EVENTS IN SWGondwanA, 1, Extended Abstracts..., São Paulo, IGCP Project 478, p. 18-19.

Figueiredo MF, Babinski M, Alvarenga CJS, Pinho FEC AND Simon CM. 2006. Chemostratigraphy (C, O and $\mathrm{Sr}$ ) of Ediacaran post-glacial carbonates of Paraguay 
Belt, Mato Grosso State, Brazil. In: South AMERICAN Symposium on Isotope Geology, 5, Extended Abstracts, Punta del Este, IGCP Project 478, p. 307-311.

Gaucher C, Boggiani PC, Sprechmann P, Sial AN AND FAIRCHILD T. 2003. Integrated correlation of the Vendian to Cambrian Arroyo del Soldado and Corumbá Groups (Uruguay and Brazil): Palaeogeographic, palaeoclimatic and palaeobiologic implications. Precambrian Res 120: 241-278.

GERMS GJB. 1972. New shelly fossils from Nama Group, South-West Africa. Am J Sci 272: 752-761.

GRANT SWF. 1990. Shell structure and distribution of Cloudina, a potential index fossil for the terminal Proterozoic. Am J Sci 290-A: 261-294.

Halverson GP, Hoffman PF, Schrag D, Maloof A AND RicE AHN. 2005. Toward a Neoproterozoic composite carbon isotopic record. Geol Soc Am Bull 117: 1181-1207.

HofFMAn PF AND Schrag DP. 2002. The Snowball Earth hyphothesis: testing the limits of global change. Terra Nova 14: 129-155.

JaCOBSEn SB And Kaufman AJ. 1999. The Sr, C and $\mathrm{O}$ isotopic evolution of Neoproterozoic seawater. Chem Geol 161: 37-57.

Nogueira ACR, Riccomini C, Sial AN, Moura CAV AND FAIRCHILD TR. 2003. Soft-sediment deformation at the Neoproterozoic Puga cap carbonate (southwestern Amazon Craton, Brazil): confirmation of rapid icehouse to greenhouse transition in snowball Earth. Geology 31: 613-616.
Nogueira ACR, Riccomini C, Sial AN, Moura CAV, TRINDADE RIF AND FAIRCHILD TR. 2007. Carbon and strontium isotope fluctuations and paleoceanographic changes in the late Neoproterozoic Araras carbonate platform, southern Amazon craton, Brazil. Chem Geol 237: 186-208.

PFEIL RW AND READ JF. 1980. Cambrian carbonate platform margin facies, shady dolomite, southwestern Virginia, USA. J Sediment Petrol 50: 91-116.

Trindade RIF, Font E, D'Agrella-Filho MS, NoGUEIRA ACR AND Riccomini C. 2003. Low-latitude and multiple geomagnetic reversals in the Neproterozoic Puga cap carbonate, Amazon craton. Terra Nova 15: 441446.

Trompette R. 1994. Geology of Western Gondwana 2000500 Ma: The Pan-African - Brasiliano amalgamation of South America and adjacent Africa. Rotterdam, Balkema, $366 \mathrm{p}$.

Trompette R. 2000. Gondwana evolution; its assembly at around 600 Ma. Acad Sci Paris, Sciences de la Terre et des planètes. Earth and Planetary Sciences 330: 305-315.

ZAINE MF AND FAIRCHILD TR. 1985. Comparision of Aulophycus lucianoi, Beurlen \& Sommer from Ladário (MS) and the genus Cloudina, Germs, Ediacarian of Namíbia. An Acad Bras Cienc 57: 130.

ZAINE MF AND FAIRCHILD TR. 1992. Considerações paleoambientais sobre a Formação Araras, Faixa Paraguai, Estado do Mato Grosso. Bol Resumos Expandidos, 37. Cong Bras Geol, São Paulo, SP, Brasil. SBG 2: 474-475. 